\title{
Questions of quality: The Danish State Serum Institute, Thorvald Madsen and Biological Standardisation
}

\begin{abstract}
Anne Hardy
Published in Christoph Gradmann and Jonathan Simon eds, Evaluating and

Standardizing Therapeutic Agents, 1890-1950 (Basingstoke: Palgrave MacMillan, 2010): 139-152.

The opening of the Danish State Serum Institute in Copenhagen on 9 September 1902 was a festive occasion, attended by renowned figures from the wider bacteriological community including the German scientists Paul Ehrlich, Carl Weigert, and Julius Morgenroth, future Nobel prize-winner Svante Arrhenius from Sweden, Ole Malm and Armauer Hansen from Norway, and William Bulloch and German Sims Woodhead from England. ${ }^{1}$ Established as a national resource for the production of diphtheria antitoxin, the DSSI was from its inception concerned to deliver a quality product at a minimum price, and to link pharmaceutical production with research into, and further development of, biological products. In the course of the twentieth century, the institute acquired an international reputation for the quality of its products and its cutting edge research, and, in the 1920s, achieved international authority as the League of Nations Health Commission's central laboratory for the preservation and distribution of all standard sera and bacterial products. ${ }^{2}$ The rise of the DSSI to international prominence came about through a combination of factors, personal, scientific and political, but above all, perhaps, from its early association with questions of quality in the production of the new generation biological medicines, of which diphtheria anti toxin was the first to emerge.
\end{abstract}

\section{Diphtheria and the Development of the Danish State Serum Institute}

The creation of the DSSI was largely due to the energy and determination of Carl Julius Salomonsen (1847-1924), the 'father of danish bacteriology', ${ }^{3}$ for Danish medical culture at that period was largely traditional with a focus on hospital medicine and general practice, rather than on research, let alone bacteriology. ${ }^{4}$ Late nineteenth-century Denmark was a small state on the European periphery, with a population of only some ...., which was then beginning to adopt progressive social welfare policies in emulation of the German welfare model elaborated from the mid-

\footnotetext{
1 T. Madsen, Statens Serum Institut (Copenhagen, 1940), p. 21.

2 R. Gautier, 'The Health Organisation and biological standardisation', Quarterly Bulletin of the Health Organisation 4 (1935): 499-554, pp. 501, 504.

3 T. Madsen, 'Carl Julius Salomonsen (1847-1924)', Journal of Pathology and Bacteriology 28 (1925): 702-708, p. 702.

${ }^{4}$ See, for example, T. Madsen, 'Dr Thorvald Madsen fortæller', Medicinsk Forum 6 (1953): 197-205, pp. 198-202; C. J. Salomonsen, 'Reminiscences of the summer semester, 1877, at Breslau', ed. C.L. Temkin, Bulletin of the History of Medicine 24 (1950): 333-351, p. 344
} 
1880s - a political context which helped Salomonsen's promotion of several medical projects. ${ }^{5}$ Like almost every European state at this period, the country suffered severely from epidemic diphtheria in the years between c. 1880 and 1895; at the peak in 1893 a total of 23,695 cases were notified. ${ }^{6}$ Public concern over the domestic tragedies resulting from this epidemic was considerable, and was not helped by press publicity. In 1890, for example, one of the leading Danish newspapers carried an article which graphically described the diphtheria wards at Copenhagen's isolation hospital where 'tragic children struggle against powerful death'. The article concluded: ${ }^{7}$

We understand mothers' terror of this dreadful disease, that now kills at once, now kills when the child is convalescent. Diphtheria is nearly always followed by paralysis in the throat or the heart. When one believes a little child has recovered, it is suddenly overtaken by a heart attack, and tumbles over on the floor in its play, dead. (Author's translation)

In this context, Emile Roux' announcement in the summer of 1894 of the successful diphtheria antitoxin trials generated, as elsewhere, significant interest from a wide section of the general public as well as within the small medical community.

The significant mortalities and vivid popular anxieties which still surrounded several major infectious diseases in the 1880s generated perilous hopes of the new knowledge and new techniques that were beginning to emerge from the bacteriological laboratories. Although, as Jonathan Simon notes, Roux was surprised by the avid public interest in the new anti-diphtheria serum in 1894, his reaction seems odd, even naïve. Given the intense popular anxieties that surrounded the disease, such a reaction seems predictable - more especially since precisely such an overwhelming public response had greeted Robert Koch's announcement of an apparent cure for tuberculosis in $1890 .^{8}$ The new therapies quickly altered public expectations and popular practices; the introduction of serum therapy and laboratory diagnosis, for example, reconciled the middle classes to hospital treatment for their sick offspring. ${ }^{9}$ On the one hand anxiety generated popular interest and support for these new treatments, but on the other they could also generate new concerns. Deaths associated with the new treatments, such as that of Ernst Langerhans described by Axel Huntelman, indicated that these novel therapies were not without risks, and could not be accepted as an unconditional good..$^{10}$

The introduction of these new therapies was in fact far from straightforward. Public acclaim and public suspicion, scientific rivalry, financial considerations and ethical issues surrounded their introduction into clinical practice. In the last two decades of the nineteenth century, the scientists who pioneered these techniques

\footnotetext{
5 For Danish medical organisation and culture see J. Lehmann, J. Carlson and A. Ulrik eds, Denmark: Its Medical Organisation, Hygiene and Demography (Copenhagen and London, 1891).

${ }^{6}$ Ibid, pp. 319-20.

7 'Mellem dodsyge. Et besog ved midnat', Politiken 15 December 1890, cited in K. Jensen, Bekaempelse af infektionssygdomme (Copenhagen, 2002), p. 18.

${ }^{8}$ See C. Gradmann, Krankheit im Labor: Robert Koch und der Medicinische Bakteriologie (Gottingen, 2005); T. D. Brock, Robert Koch: A Life in Medicine and Bacteriology (Madison Wisconsin, 1988), pp. 201-05.

9 P. Weindling, 'From medical research to clinical practice: serum therapy for diphtheria in the 1890s', in J.V. Pickstone ed, Medical Innovations in Historical Perspective (Basingstoke, 1992), pp. 72-83.

${ }^{10}$ A. Hüntelmann, 'Das diphtherie-serum und der fall Langerhans', Med GG, 24 (2006), pp. 71-104.
} 
learned, faute de mieux, to negotiate conflicting sets of interests. They also learned, gradually and sometimes painfully, that to be successful the new techniques required precision of method, the setting of standards, and the implementation of hygienic practices. It is often forgotten that the young science of bacteriology emerged in a scientific world where standards of scientific practice were rudimentary. Koch's postulates were only one small step on the road to modern science; the success of both scientific experiment and commercial manufacture could depend crucially on the physical environment of the laboratory. One of the most striking features of the memoirs by distinguished Danish practitioners written about the early years of bacteriology is the lasting impression of habitual chaos in the laboratories of the period 1870 to 1900 . The Danes were proud of having been the first to adopt antiseptic practices, ${ }^{11}$ and were somewhat shocked by failures to recognise the importance of the practice in both Germany and Paris, while the filthy conditions prevailing in many prestigious laboratories were also a source of remark. As on observer later noted: 'The laboratories then were uniformly depressing to look at, grey or brown and often terribly dirty. Apparatus and bottles filled the tables, racks of halffull test-tubes were the order of the day, and there was generally a prohibition on moving anything'. ${ }^{12}$ Pasteur and Ehrlich's labs were no exception, and when the League of Nations Health Commission in the 1920s held a laboratory conference at the Institut Pasteur in Paris, the designated rooms were so dirty that it took several days' cleaning before they were useable. ${ }^{13}$ Asked if these distinguished bacteriologists had no sense of order and cleanliness, this witness replied that laboratory equipment was then less highly regarded, and that researchers were perhaps also under the impression that if people like Pasteur could make groundbreaking discoveries in a filthy room in the Rue d'Ulm, then lesser spirits were in no position to demand better conditions. ${ }^{14}$

More scrupulous laboratory practice and protocols did however develop with, sometimes bitter, experience. The new biological therapies that began to emerge after 1880 were of a very different nature from the traditional galenic medicaments. They were not compounded from inert organic and inorganic substances but prepared with and from living organisms and live body fluids. As live preparations, these biological products were more volatile than the drugs derived from the pharmacopeia; they could vary unpredictably in strength, and in their reactions with other living material. They contained in themselves the unpredictable essence of nature. Late nineteenth-century researchers were still learning not only how to make and handle such substances but also the importance of precision if effective replication was to be achieved. As Gabriel Gachelin points out, early descriptions of the anthrax and rabies vaccines published from the Pasteur Institute were 'rather imprecise' (p. 9) as to the technical procedures used, while Robert Koch notoriously withheld any details of the manufacture and testingof tuberculin in 1890. By contrast, Emile Roux and Louis Martin were quick to publish detailed descriptions of the protocols for the isolation and inactivation of diphtheria toxin in 1894 (ibid.). ${ }^{15}$ That publication, together with the generosity which the French researchers showed in welcoming visitors to the Pasteur Institute and instructing them in their methods of production, ensured that

\footnotetext{
11 Salomonsen, 'Summer semester', p.345.

12 T. Madsen, 'Dr Thorvald Madsen fortæller. II', Medicinsk Forum 9 (1956): 161-177, p. 161.

13 Ibid, p. 162.

14 Ibid.

15 .E. Roux and L Martin, 'Contribution a l'étude de la diphtherie (serum therapie)', Annales Institut

Pasteur, 8 (1894): 609-39
} 
manufacture of the antitoxin serum became a possibility even in laboratories on the European periphery. ${ }^{16}$

National responses to the possibilities of diphtheria antitoxin varied. While the excitement generated by the promise of the new therapy spread widely, different communities took the initiative towards implementing introduction and manufacture in different places. In Geneva and in London, the initiative came from the private sector: in Geneva from the women's branch of the Samaritans, as Mariama Kaba shows; in London the privately-funded British Institute for Preventive Medicine (later the Jenner, then the Lister), then under the direction of Pasteur protégé Armand Rueffer, set up a Serum Department as early as August $1894 .{ }^{17}$ In Denmark, the incentive came from Copenhagen University's professor of microbiology, Carl Julius Salomonsen. ${ }^{18}$ Patterns of manufacture and distribution also varied, as they became established. In Britain and in Germany, production passed to commercial companies. ${ }^{19}$ In France, locally funded provincial serotherapy facilities, acting under the umbrella of the Pasteur Institute in Paris, supplemented the activities of the Paris centre, which operate a quasi-monopoly of serum production in France. ${ }^{20}$ In Denmark, serum production began in a university facility but became formalised under state patronage and transformed into a national facility. ${ }^{21}$

The history of the Danish State Serum Institute, as previously noted, is of much more than purely national significance. Under the leadership of its second Director, the suave, cosmopolitan Thorvald Madsen (1870-1957), the DSSI achieved an international reputation for the quality of its products and the status of arbiter of international standards in the production of biological medicines. Although microbiology in late nineteenth-century Denmark was a minute enterprise compared with the programmes and personnel active in the bacteriological heartlands of France and Germany, it was fronted by powerful, well-connected personalities possessed of a clear sense of scientific and human priorities. Carl Julius Salomonsen and Thorvald Madsen were between them the architects of the DSSI and its subsequent reputation.

Carl Julius Salomonsen had initially trained as a doctor in Copenhagen, but was seriously attracted to the study of microbiology, and spent an enjoyable and profitable summer working under been Julius Connheim's instruction at Breslau in $1877 .^{22}$ Here he made the acquaintance, among others, of Paul Ehrlich and William Welch, and completed an important study of tuberculosis in the eye of the rabbit. ${ }^{23}$ On his return home he was appointed to teach microbiology at Copenhagen University, the first such lecturer to be appointed in any university. His small laboratory was located in a basement under the Botanic Gardens Museum, and here he conducted the first ever taught course in bacteriology. ${ }^{24}$ Salomonsen was among the many fired with enthusiasm for Roux' new therapy, and in September 1894 he travelled to Paris to study it. He was given every facility to familiarise himself with the processes of

\footnotetext{
${ }^{16}$ Jensen, Bekampelse, p. 22

17 R. Church and E. M. Tansey, Burroughs Wellcome \& Co: Knowledge, Trust, Profit and the

Transformation of the British Pharmaceutical Industry, 1880-1940 (Lancaster, 2007), p. 203

18 Jensen, Bekcempelse, p. 22

19 Church and Tansey, Burroughs Wellcome, chapter 7

${ }^{20}$ Jonathan Simon, 'Quality control and the politics of serum production', this volume, pp. 89-104;

Gabriel Gachelin, 'The construction of a culture of standardization at the Institut Pasteur (1885-1900)', this volume, pp. 71-88.

21 Jensen, Bekampelse, chapter 1

22 See Salomonson, 'Summer semester'.

23 Madsen, 'Salomonsen', pp. 704-5.

24 Ibid.
} 
production, remarking particularly on the generosity of the French researchers in this respect. $^{25}$ Back in Copenhagen, Salomonsen successfully sought financial support from the Ministry of Education for a serum production facility and the training of two young co-workers. In November 1894 he established a serotherapy department in two small rooms within the university Medical Bacteriology Laboratory on $\mathrm{Ny}$ Vestergade. His team consisted of Thorvald Madsen, who had previously taken his bacteriology course, and who had qualified as a doctor the previous year; Miss Louise Hoeg, as under-assistant, and a laboratory technician, N. Rasmussen. Salomonsen's ambition for this department was two-fold. First, that it should produce diphtheria antitoxin for free distribution to Danish doctors and hospitals; and second, that it should engage in research into the processes of immunity. ${ }^{26}$

It was soon discovered that serum production was a lengthy procedure with unpredictable outcomes. Just as the facility at Nancy began the immunisation process in November 1894 but was unable to supply the local hospitals until February 1895, ${ }^{27}$ so it was not until June 1895 that the first home-produced serum reached Copenhagen's Blegdamshospital. ${ }^{28}$ It was not just that the immunized horses took a couple of months for their serum to ripen. The Danes also experienced much greater difficulty in developing a satisfactory product than Salomonsen had anticipated, and assistance was not forthcoming from elsewhere. 'It must be remembered', he recalled, 'that at that time the few existing serum manufactories which possessed a greater experience in the matter than ourselves, had, in the interests of their business, preserved an absolute silence with regard to their methods and results' ${ }^{29}$ The reticence of the successful manufacturers greatly increased the difficulties experienced by new would-be producers: they had to negotiate the same learning curve as everyone else. They learnt the hard way that the strength of strains of diphtheria bacillus attenuated with time; that the strength of serum produced by individual horses varied, and also depended on the strength of the toxin used, the mode of immunisation, and the time of bleeding; and 'upon other circumstances as well, of which we possess as little knowledge as of the varying toxigenic power of the diphtheria bacillus'. ${ }^{30}$ The importance of measuring the strength of a given serum was identified early, and remained a constant concern. Writing on the occasion of the opening of the SSI in 1902, Salomonsen noted, 'It is this enigmatical uncertainty on all the chief points that makes the production of the serum both very expensive and very precarious'. ${ }^{31}$ In his report for 1903-08, Thorvald Madsen echoed these sentiments: 'Serum production is still from day to day a very difficult and uncertain business'. The sentence was to appear practically unaltered some thirty years later, in his report for $1940 .^{32}$

Despite all difficulties, the Danish serum project was taken steadily forward, encouraged by disappointing experiences with imported German serum in the Blegdamshospital in the autumn of $1894 .{ }^{33}$ Salomonsen's ambition to produce enough serum for the whole country was underpinned by a determination not to spend

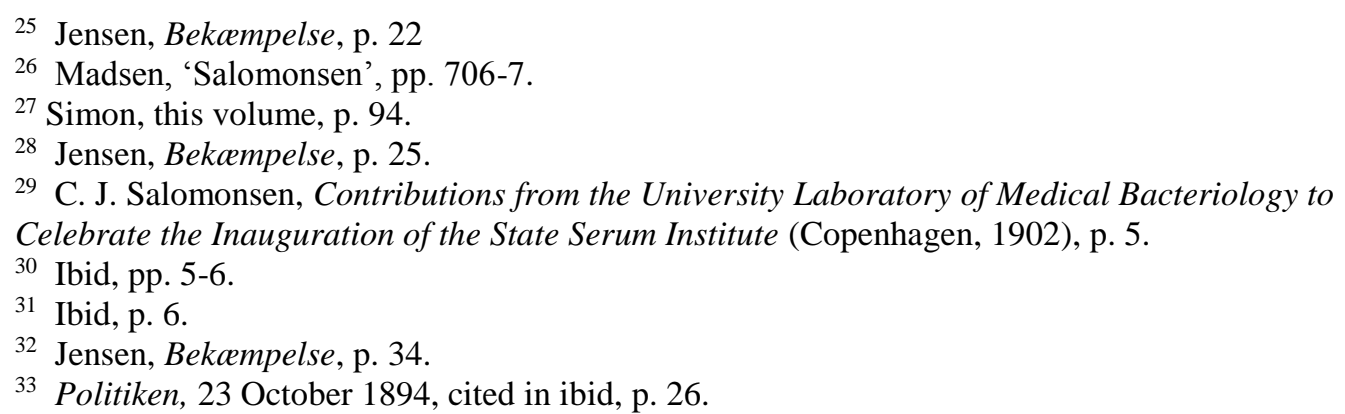


national resources on expensive German commercial imports of variable quality. ${ }^{34}$ In the end, co-operation with the British Institute for Preventive Medicine, who donated a powerful diphtheria strain, resulted in a satisfactory outcome. The production method eventually adopted followed the BIPM's very closely, but the methods of measurement were, 'of course', those of Paul Ehrlich. ${ }^{35}$ Ehrlich had been a very constant friend to the Danish project. ${ }^{36}$ Salomonsen had met him in Breslau in 1977, and he and Thorvald Madsen visited Ehrlich in 1899. Moreover. Madsen's doctoral dissertation, completed in 1896, endorsed Ehrlich's methods of measuring serum quality as superior to the French. ${ }^{37}$ Madsen long maintained warm sympathies for his Germany and his German colleagues, and Ehrlich's work remained a powerful influence within the SSI for many years. ${ }^{38}$ Cay Pruell has noted the importance of Ehrlich's influence on Henry Dale as a formative contribution to Dale's role in achieving international standards for insulin in the 1920s (Chapter 1 this volume), but Ehrlich's influence on Thorvald Madsen, who was to chair the LNO Health Commission for much of its existence, and who was a prime mover in establishing the Commission's committee on Biological Standards, was perhaps of greater significance to the interwar biological standardisation project in general.

\section{Thorvald Madsen, diphtheria and the DSSI.}

Thorvald Madsen was, as we have seen, appointed director and researcher of Salomonsen's small serum production facility in 1894 . He was then a very newly qualified doctor, who had come to Salomonsen's attention as one of only two students attending the microbiology course a few years earlier. ${ }^{39}$ Moreover, he came to the post with a particular personal interest: he himself had been hospitalised with diphtheria in 1889, and his youngest sister had died of the disease at the same time. ${ }^{40}$ Although Madsen himself never refers to this incident in any of his memoirs, it is generally assumed that this experience was not unconnected to his later scientific interests. ${ }^{41}$ While Johannes Fibiger, also a former student of Salomonsen, was conducting his more famous study of the outcomes of antitoxin use in the Blegdamshospital, Madsen was conducting a landmark comparative study of the French and German methods of serum production and measurement for his doctoral dissertation, completed in $1896 .{ }^{42}$ Although Gachelin has emphasised the importance of knowledge transfers in respect of serum evaluation between France and Germany and the similarity of their methods, Madsen concluded that the German methods those of Paul Ehrlich - were superior to the French. The dissertation ("Experimental investigations into diphtheria toxin") concluded with the observation: ${ }^{43}$

\footnotetext{
34 Jensen, Bekampelse, p. 31.

35 Salomonsen, Contributions, p. 6.

36 Ibid.

${ }^{37}$ E. Schelde-Møller, Thorvald Madsen i Videnskabens og Menneskenhedens Tjeneste (Copenhagen, 1970), p. 41.

38 Madsen's strong pro-German sympathies were reported by a French observer at the League of Nations Health Commission in the early months of World War II. I am grateful to Iris Borowy for this reference.

39 Madsen, 'Madsen fortæller', p. 198

40 Schelde-Møller, Madsen, p. 29.

41 Ibid; see also Jensen, Bekampelse, p. 22.

42 T. Madsen, 'Experimentelle undersogelser over difterigiften' (unpublished $\mathrm{PhD}$ thesis, Copenhagen, 1896).

${ }^{43}$ Cited in Schelde-Møller, Madsen, p. 41.
} 
It would be of the greatest significance for these measurements, if agreement could be reached on an international unit for determining the strength of the antidiphtheria serum

When Madsen visited Ehrlich as part of his bacteriological 'Grand Tour' in 1899, he found himself in high favour with Ehrlich as a result of his doctoral work, and he clearly felt very much at home with Ehrlich and his colleagues. ${ }^{44}$ By contrast, a visit to the Institut Pasteur was less congenial: 'It was one of those places where you dumped down in a corner, and no one paid any further attention to you' ${ }^{45}$ It seems apparent that, from the beginning, Paul Ehrlich stood as patron and god-father to the Danish serotherapy enterprise, and his presence as an honoured guest at the inaugural festivities for the new Serum Institute in 1902 reflected that fact.

The translation from a small university facility to a state-funded, purpose-built institute was achieved through a combination of circumstances. In the first place, diphtheria remained an acute concern for the Danish people, and medical demand for the new serum was rising; secondly, the Danish state was already embarked on a programme of infectious disease control. ${ }^{46}$ Finally, Salomonsen was a man of some determination when he had identified a project, as his achievements of the initial serum production unit, and later of Denmark's first Institute of Pathology, prove; and Madsen was well-connected politically, his father being Minister of War between 1901 and 1904. When, in 1898, Denmark's hospital physicians united in calling for the further development of the serum facility so that all the country's doctors could be supplied with diphtheria antiserum free of charge, Salomonsen took action and approached the Ministry of Education. ${ }^{47}$ While the Ministry and the University's Medical Faculty considered how best to establish a new and extended facility, Salomonsen and Madsen identified a suitable site for the new facility on War Ministry property on the island of Amager, lying just across a narrow strait south of the mainland city. ${ }^{48}$ Delayed by various political complications, the State Serum Institute Act was finally passed in spring 1901.

The first clause of the Act provided for the establishment of an Institute for the production of diphtheria antiserum, ${ }^{49}$

... under the jurisdiction of the Ministry of Justice. It shall undertake to supply such serum on the largest possible scale to the medical men of this country and its colonies, on application to the said Institute.

The sum of 172,800 Danish kroner was set aside to provide for the new buildings on Amager Common, and the sum of 23,000 kroner per annum was provided to meet running costs. Government priorities for the new Institute were reflected in its governance provisions: the Institute Director was to receive a salary of 1,000 kroner a year, but the Laboratory Director responsible for serum manufacture, the work

\footnotetext{
${ }^{44}$ Madsen, 'Madsen fortæller I', pp. 203-6.

45 Ibid, p. 208.

46 See Lehmann et al, Denmark, pp. 65-128.

47 Salomonsen, Contributions, p. 10

48 Ibid, p. 13.

49 Ibid.
} 
connected with it, and for directing research, was to receive an annual 3,200 kroner, with an incremental increase of 600 kroner every 5 years, to a maximum of 5,600 kroner. ${ }^{50}$ Thus Salomonsen as Director of the Institute was considered a far less important figure than Madsen as Director of the Laboratory with responsibility for the day to day functioning and production.

The original intention had been for the SSI to deliver its products to the medical community free of charge, but the 1901 Act actually specified that the product be sold. The Ministry of Justice managed to circumvent this provision with the consent of parliament, setting the price so low as to cause minimal inconvenience to existing supply agreements. At a price of 25 øre (100 to the krone) per dose, the DSSI price compared very favourably to the $6 \mathrm{kr} 25 \emptyset$ re charged by the German commercial firms. ${ }^{51}$ Where the small University serum facility had been stretched to produce 6,305 doses of antiserum in 1901-02, the SSI in its first full year of production (1903) produced 8,800 doses. ${ }^{52}$ At this time it staff was barely larger than when in Ny Vestergade: it consisted initially of Madsen, Louise Hoeg, a watchman and a stable-master. The first research assistant arrived six months after the building opened, by which time the DSSI was already making a name for itself. The first foreign visitor was Hideyeo Noguchi, who came to study under Madsen in 1903, but eminent scientific guests over the years came to include Theobald Smith, Elie Metchnikoff, William Welch, Robert Koch and Jules Bordet, besides a constant stream of lesser luminaries. ${ }^{53}$ The DSSI had quickly come to represent a gold standard in the production of biologicals.

In the years that followed, the DSSI began to accrue additional responsibilities for bacteriological and serological diagnoses, as the field developed, and as anxieties about diseases other than diphtheria came into existence. Such work in turn generated related research projects. A new small laboratory for the study of plague and cholera was approved in 1908, just as it was realised that the Wasserman test had important consequences for the diagnosis and medical control of syphilis. The perceived necessity of giving private practitioners and hospitals access to the new procedure precipitated plans for a major expansion of the SSI's remit and facilities. ${ }^{54}$ The newly established government Health Commission, which had the brief to organise Denmark's civilian health administration, recognised the DSSI as the country's central laboratory for epidemiological and serological research in support of the Commission's remit, and supported the proposed expansion. The law enabling the DSSI's physical and scientific expansion was enacted in $1910 .{ }^{55}$ At the same time, the Health Commission articulated its expectations of the newly expanded establishment: ${ }^{56}$

The Health Commission strongly emphasises that the Institute is established as a humane and socially useful institution, and it therefore regards any attempt to make this facility a directly profitable undertaking as highly regrettable ... not only on humanitarian grounds, but also because by the reduction in the

\footnotetext{
50 Ibid, p. 14

51 Jensen, Bekampelse, p. 34

52 Salomonsen, p. 7; Jensen, Bekampelse, p. 34.

53 Madsen, Staten's Seruminstitut, pp. 14-15. See also Madsen, 'Hideyo Noguchi', Medicinsk Forum, 13 (1960): 112-3.

54 Madsen, Staten's Seruminstitut, pp. 22-25.

55 Jensen, Bekcempelse, p. 36

56 Madsen, Staten's Seruminstitut, pp. 26-9.
} 
costs of hospitals and epidemics, and in the losses incurred by commerce and transport resulting from epidemics, it will achieve a much greater compensation for its outlay. (Author's translation)

A clear recognition of the economic benefits to be obtained by supporting the production of and research into biological medicines underpinned the Danish government's continuing financial support for the expansion of the SSI.

The scientific expansion of the SSI beyond the initial remit of diphtheria antiserum production was presided over by Thorvald Madsen, initially as Director of the Laboratory and, from 1 April 1909, on Salomonsen's retirement from the post to concentrate on the University's new Ordinary Pathology ('Almindelig patologi') facility, also as Director of the Institute. ${ }^{57}$ In taking on these new responsibilities, Madsen's aim remained clear: the development and production of high-class biological medicines for the prevention and treatment of human disease.

\section{The DSSI and Biological Standardisation}

Quality in the production of biologicals was an issue for the Danish serotherapy community even before the establishment of the DSSI. Madsen's doctoral thesis, as we have seen, marked an early interest in issues of comparability, quality and standardisation, and this proved an enduring pre-occupation in the context of the DSSI's ambition to provide the best possible products at the lowest possible price. With the development of an international trade in antitoxin after 1894, concerns over the relative strength of the different products on the market became rife. Physicians needed to know how many units or millilitres of serum were needed for individual patients. German, French, Danish and English sera came in varying strengths and qualities, but these differences might not be immediately apparent, unless the place of production was carefully noted. Although the 'unit' (the smallest amount of serum that would neutralise the smallest lethal dose of toxin in a mouse or guinea pig) as the standard measurement of strength was adopted early, it became apparent that different national units were not one and the same thing. Differing biological characteristics between populations of laboratory animals significantly affected the comparative quality of the final product. As historian Karl Jensen observes: ${ }^{58}$

The Germans used some very sensitive mice, the French mice were sound as bells and difficult to kill, while the English mice were pure rubbish. For this reason the French antitoxin unit was stronger than the German which in turn was stronger than the English. (Author's translation)

The differences were significant enough for the English Lancet Comission on diphtheria antitoxin of 1896 to conclude that the English products did not work. ${ }^{59}$

The biological problems of standardization quickly became central to the research conducted at the SSI. In 1897, Madsen and Salomonsen demonstrated that there were significant differences in the ability of various sera to neutralize toxins.

\footnotetext{
${ }^{57}$ Schelde-Møller, Madsen, p. 53.

58 Jensen, Bekampelse, p. 66

${ }^{59}$ Lancet, 1896, ii: 182-95, 96.
} 
Some horses produced poor antitoxin, others a high quality product. ${ }^{60}$ In that year, however, Paul Ehrlich produced his ingenious solution to these problems as regarded the diphtheria antitoxin by developing a standardized antitoxin preparation, which prepared the way for the later standardization of a whole range of biologicals, from toxins and antitoxins to insulin and penicillin. ${ }^{61}$ From 1897 until the outbreak of World War I, Ehrlich's preparation was internationally accepted as the standard for all diphtheria antitoxins. Problems of comparability resurged, however, in the political and scientific fragmentation associated with war. Within weeks of the outbreak of hostilities, tetanus had become a serious problem among the wounded of all combatants on the Western Front. Both British and German military authorities sent urgent requests for supplies of anti-tetanus serum across Europe, and production was stepped up in many areas outside the military zones. In Denmark, neutral in this war, but economically heavily dependent on both England and Germany before 1914, production was hurriedly expanded.

The level of wartime demand for the tetanus antiserum may be illuminated by the British experience, From August to October 1914 there were no definite instructions on the administration of antitoxin to the wounded. From the middle of October every wounded man was given a dose of 500 units; from June 1917 dosage was increased to four doses of 500 units at weekly intervals. ${ }^{62}$ This reduced the incidence of tetanus to 1 per 1000 wounded. Given the number of casualties, vast quantities of antiserum were required to meet demand. Denmark's response to military demands may not have been typical, but is suggestive of the efforts that were made across Europe to meet the military requirements. At the outbreak of war the SSI maintained just two 'tetanus horses' - enough to meet the national need in peacetime. As the calls began to come from the front, Madsen sent his stable-master out to buy horses, managing to acquire a further 46 animals in the teeth of aggressive German buying to meet demand on the battlefield. By the end of the war, the SSI's stable of tetanus horses numbered around one hundred animals. ${ }^{63}$

As a result of extensive laboratory efforts at expended production, death rates on the battlefields began to fall by early 1915, but with the pan-European and American involvement in production, issues of standards soon became apparent. One German unit was discovered to be the equivalent of 67 American units, or of around 3000 French units. As Madsen observed: 'The unfortunate doctors, who . . . had to use tetanus serum from many different countries, were often terribly dis-oriented when it came to dosage' ${ }^{64}$ René Gautier, Secretary of the League of Nations Health Organization's Permanent Committee on Biological Standards, phrased it rather more trenchantly: ${ }^{65}$

Many deaths could have been averted if the sera used during the war had been assayed in relation to a unique standard. Doctors would not have been betrayed by the unitage given on foreign ampoules into injecting quantities of serum which they had good reason to regard as sufficient, but which were in

\footnotetext{
${ }^{60}$ Jensen, Bekampelse, p. 66; see also Salomonsen, Contributions, pp. 8-10, for bibliographical references.

${ }^{61}$ Jensen, Bekampelse, p. 67.

62 J. Boyd, 'Tetanus in two World Wars', Proceedings of the Royal Society of Medicine, 53 (1958), 109-10, p. 109.

${ }^{63}$ Schelde-Møller, Madsen, p.86, 110; Jensen, Bekampelse, pp. 51-2.

${ }^{64}$ Schelde-Møller, Madsen, p. 110.

${ }^{65}$ Gautier, 'The Health Organisation', p. 500
} 
fact inadequate, since the assay had been effected in terms of a unit of lesser potency than that to which they were accustomed.

Wartime experience thus dramatically reinforced the realization of the necessity for internationally accepted biological standards being agreed upon and implemented.

Biological standardization was one of the first issues taken up by the League of Nations Health Committee after the war, at least in part because Thorvald Madsen had been appointed its President - a position he was to hold until 1937. At the Committee's second session, held at Geneva in 1921, Madsen proposed international collaboration on the question of biological standardization. ${ }^{66}$ As Pauline Mazumdar shows in her chapter, such international collaboration, on a topic which necessitated the involvement of French and German scientists as leading authorities in the field, was by no means easy in the initial aftermath of the war. Madsen's diplomatic skills, the networks of scientific association he had built up in the pre-war years, the standing which he and the DSSI had already achieved in this new field, and his own recognition of the importance of the standardization project to future developments in international health, were critical in enabling the achievement of the Heath Committee's international collaborative effort,

\section{Biological Standardization in Context}

The interwar biological standardization project was not, therefore, primarily initiated in response to problems with diphtheria antitoxin preparations. None the less, Paul Ehrlich's pioneering work in standardizing the diphtheria antitoxin had established the scientific basis from which work in respect of other pathogens could go forward in the interwar period when the principle found general application in pharmacology, physiology and bacteriology. ${ }^{67}$ Writing in the early 1940s, the Danish bacteriologist and DSSI researcher Johannes Ipsen, whose own work was to put biological standardization on a new plane after1945, recorded that the adoption of the procedure was the result of intensive international co-operation, sponsored in particular by the League of Nations Health Committee under the direction of Thorvald Madsen. Three countries, Ipsen noted, were principally involved in this work, although many institutions had shared in the establishment of standards and preparations for series of hormones, vaccines and sera. Those three countries were Germany, where the traditions created by Paul Ehrlich had been maintained by the Frankfurt Institute; England, 'the home of modern biometry'; and Denmark, which 'has contributed greatly to the biological standardization under the leadership of Aug. Krogh and Th. Madsen' ${ }^{68}$ In other words, Germany had set the standards; England provided the mathematical means for calculation; and Denmark the bacteriological and physiological underpinning of the standardization project.

Modern historians of the early decades of bacteriology have tended to focus on contributions from the two great pioneering nations of the young science, Germany and France, as well as on such leading figures as Louis Pasteur, Robert Koch and Paul Ehrlich. But bacteriology rapidly became an international science, whose fascination attracted world-class scientists across the globe, many of whose contributions remain

\footnotetext{
${ }^{66}$ Gautier, 'The Health Organisation', p. 500; Jensen, Bekampelse, p.68.

${ }^{67}$ J. Ipsen, Contribution to the Theory of Biological Standardization (Copenhagen, 1941), p. 11.

${ }^{68}$ Ipsen, Contribution, p. 11; August Krogh (1874-1949), Nobel Prize winner, 1920: see B. SchmidtNielsen, August and Marie Krogh: Lives in Science (Oxford, 1995).
} 
as yet under-explored and under-valued by historians. In the case of Denmark, a handful of scientists working initially in primitive conditions in a small country on Europe's Nordic fringe, played a critical role in the eventual establishment and implementation of internationally accepted standards for the ground-breaking biological therapeutic innovations that derived from the new science. Biological standardization was a core interest of the DSSI from its earliest incarnation as a centre of production for the anti-diphtheritic serum, and it was a particular interest of Thorvald Madsen, who developed into one of the subtlest medical politicians operating on the international stage during the interwar years. While Germany and France were the colossi that bestrode the world of bacteriology before World War I, it was Denmark, with its particular concern for biological standards, that can be seen as a crucial connecting thread, especially in the pulling together of the international standardization project of the interwar period. 